\title{
Can the phenomenon of humour serve as an interpretive key to understand the idea of laughter in the Old Testament?
}

\author{
Author: \\ Hennie A.J. Kruger ${ }^{1}$ \\ Affiliation \\ ${ }^{1}$ School of Religion, \\ Philosophy and Classics, \\ University of KwaZulu-Natal, \\ South Africa \\ Correspondence to: \\ Hennie Kruger \\ Email: \\ kruger.hennieaj@telkomsa. \\ net \\ Postal address: \\ 29 Woltemade Avenue, \\ Stellenbosch 7600 , \\ South Africa \\ Dates: \\ Received: 17 Oct. 2013 \\ Accepted: 11 Feb. 2014 \\ Published: 28 Nov. 2014 \\ How to cite this article: \\ Kruger, H.A.J., 2014, 'Can \\ the phenomenon of humour \\ serve as an interpretive \\ key to understand the \\ idea of laughter in the Old \\ Testament?', In die Skriflig \\ 48(1), Art. \#1772, 7 pages. \\ http://dx.doi.org/10.4102/ \\ ids.v48i1.1772

\section{Copyright:} \\ (C) 2014. The Authors. \\ Licensee: AOSIS \\ OpenJournals. This work \\ is licensed under the \\ Creative Commons \\ Attribution License.
}

In the past humour was frowned upon by some, but more recently it has become part of innocuous communication between members of society. Against this background, authors also claim that humour functions in the Bible. Very few, if any, are convinced that the opposite might be true. Numerous attempts have been made to determine the meaning of, and develop definitions and theories pertaining to the concept of humour. However, until now no consensus has been reached regarding these concepts. The physiological and psychological meaning of the phenomenon is noted, but the relationship between humour and literary types has attracted more attention. Determining the time of the origin of the concept may indicate a difference in meaning between a contemporary Western and ancient Near Eastern or Middle Eastern (and Israelite) understanding of laughter, humour and mockery, respectively.

Kan die verskynsel van humor dien as 'n sleutel van interpretasie om die lagbegrip in die Ou Testament te verstaan? In die verlede is humor deur sommige persone afgekeur, maar meer onlangs het die verskynsel egter 'n integrale deel van gemeensame kommunikasie in die samelewing geword. Dus beweer baie skrywers nou dat humor selfs in die Bybel voorkom. Baie min, indien enige, is daarvan oortuig dat die teenoorgestelde waar kan wees. Talle pogings is al aangewend om die betekenis van, asook ' $n$ definisie en teorie in verband met die humorkonsep te formuleer. Tot op hede is daar egter nog geen konsensus in hierdie verband bereik nie. Daar is rekening gehou met die fisiologiese en psigologiese betekenis van die verskynsel, maar die moontlike verband tussen humor en literêre vorme het egter meer aandag getrek. Die bepaling van die ontstaanstyd van die verskynsel kan onderskeidelik op 'n verskil in betekenis tussen 'n kontemporêre Westerse en ou Nabye Oosterse of MiddeOosterse (en Israelietiese) begrip van die konsepte lag, humor en bespotting dui.

\section{Introduction: Physiological and psychological aspects}

The physiological aspect relates to the well-known condition of human beings expressed by the term humour, which comes from the Latin umor [moisture or vapour] (Simpson 1979:623; Fowler 1983:252). In medieval physiology, the word was used for the four cardinal fluids in the human body, namely blood, phlegm, yellow (choler) and black bile. The relative proportions of these fluids in the body were thought to determine the physical and mental qualities as well as the disposition of the individual concerned. Therefore, if any of these predominates, it determines the temper of the mind and body. Hence the expressions sanguine, phlegmatic, choleric and melancholic humour (Fowler 1983:252; Kirkpatrick 1999:524).

It has been pointed out that psychological cases in South Africa ending in suicide, represent a figure of more or less 8000 , whilst about 80000 attempted but failed to commit suicide (Rabe 2011; Jordaan 2007). Studies have indicated that humour plays a significant role in alleviating stress and solving psychological problems. This human faculty activates certain medically related impulses, prompting chemicals that neutralise some of the problems indicated (Swanepoel 2003).

Nevertheless, the medical world produces its own dose of laughter (Malherbe 2007:9-96). It is clear that humour has a therapeutic effect on the mood of individuals and groups as well as human relations generally. It can serve as a pleasant pastime (McKenzie 1980:248-249).

\section{A growing interest in the phenomenon of humour}

People are fond of laughing. In a way, humour may raise a laugh in every sphere of life and on any occasion (Corrigan 1981:1-335; cf. De Villiers 2002:48-127). Sherrin (2001:156-283), however, 
reminds readers of the contradictory aspects related to the concept: 'All humour is based on hostility - that's why World War II was funny.' (Interjection: 'But was the Holocaust funny ...?')

\section{Sherrin (2001) cites another example:}

\author{
My final word, before I'm done, \\ Is 'Cancer can be rather fun': \\ Provided one confronts the tumour, \\ With a sufficient sense of humour.
}

Thus, one may conclude that 'a joke's a very serious thing'. ${ }^{1}$ However, Huxley's remark seems appropriate here: 'Death ... it's the only thing we haven't succeeded in completely vulgarizing' (Daintith \& Stibbs 1994:181, n. 83). However, the matter is complicated by the fact that the Old Testament contains several narratives dealing with violence - to such an extent that some have described it as 'a bloodstained book' (Theron 2004:119). God himself exterminated whole nations (cf. Joshua and Judges). How does one link this reality to humour?

However, humour may play a different role where people are mistreated in cases of, for example unjust imprisonment. During his incarceration in a Nazi camp during the Second World War, a Christian minister (Overduin 1978:41-42) reassured his fellow prisoners that: 'Two faculties will keep us spiritually fit and resilient, especially in prison. The first is faith and the second is a sense of humor.'

Recently terrorism has also been subjected to ridicule. The film director Morris issued a movie with the title 'Four Lions'. The film hackles idiotic plans and actions of terrorists (Boekkooi 2010; cf. Parker 2010).

These references indicate the wide-ranging functioning of the concept. Furthermore, in the sphere of those who read the Bible, this phenomenon seems to have been subjected to a universal 'must-be' requirement. Some have virtually baptised the biblical record in laughter and/or humour. (e.g. Corrigan 1981; Cox 1970; Exum 1984; Radday \& Brenner 1990).

\section{Orientation: Stating the problem}

Most people are willing or may actually desire an opportunity to read the Bible in terms of laughter over against its usual stern statements regarding the conduct of God and human beings. However, the problem confronting authors involved in writing about humour is the nonexistence of a definition or theory of the phenomenon (see above). Hence, we simply apply what we visualise as funny, following our own imagination.

Therefore, authors who hope to put something on paper regarding humour are in an awkward position. On the one hand, we take part in discussions dealing with humour but, on the other hand, we do not have guidelines available to apply to the text.

1.Charles Churchill ('The Ghost', 1763) quoted in Sherrin (2001).
This article represents a brief, preliminary introduction about the claim that the Bible accommodates humour. Generally speaking, virtually all of the many authors who deal with this subject classify a variety of biblical narratives as humorous literature. Against this background, some also take it for granted that the Bible (i.e. God) has a sense of humour. This problem will be addressed in the article.

Authors simply go ahead and expound biblical texts in terms of their own opinion or imagination of what humour stands for. Only now and then would one come across authors who acknowledge that their approach is expressive of their own views (Greenspoon 2013:3). However, none of the examples (Gn 4; Ex 32; Nm 22; Jdg 3, 5; 1 Sm 25; Jnh 4; Es 5-7) dealt with by Greenspoon (2013:4-11) show any sign of sound and contextual exegetical exposition.

This article offers brief discussions about the concept of humour allegedly underlying certain biblical texts. However, the article does not pretend to cover the matter comprehensively. Literature dealing with the subject represents hordes of essays, articles, comments and remarks - simply too many to be presented in a single discussion. Jewish and Christian views on the Bible are also of great importance and necessary to highlight the problem, but will not form part of the present investigation. Relevant investigations about these issues will hopefully be published in future.

Granted that everyone has the freedom to interpret biblical texts according to their own understanding, the question as stated in the title confronts authors and readers: Does the Bible accommodate literature of a humorous nature or not? To address this question, the following must be taken into account:

- Thereare, generally speaking, several obstacles hampering the understanding (functioning) of the humour concept. These difficulties are, as said before, created by the non-existence of a workable definition and/or theories regarding the subject. Be that as it may, the role played by literary types in determining the meaning of humour is taken as decisive by most authors.

- One may also ask whether religion plays any part in determining the term's functioning.

- Also, what influence does human attitude have on laughter?

- And finally, it is crucial to establish the time of the origin of the concept.

\section{A brief look at some efforts to define and develop theories regarding the concept}

As mentioned before, the most important problem confronting a study of this kind relates to the determination of a theory and definition for the term humour. In this regard, Theron (1995:594; cf. 1996; 2004) admitted that, in spite of the phenomenon being extremely popular at 
present, a comprehensive definition is still lacking. Since no definition or theory managed to gain the upper hand and widespread acceptance, a few comments will be made about the situation.

Surveys have shown that, until approximately 1970, at least 80 different theories about the concept of humour have been proposed (Preuss 1971:9, n. 1). Around 1988 a journal, appropriately entitled Humor, was launched. The approach followed by the journal provided a forum for the publication of articles on humour. Since its inception, the journal has published at least 400 relevant articles and book reviews on the topic. However, only a few articles dealing with alleged humour in the Bible were published (eg. Svebak 1996; Friedman 2000; 2002; Hempelmann 2003; Veatch 1998; Perlmutter 2000). As mentioned above, scholars are still searching for a definition and theory to determine the essence of the concept (Veatch 1998). Veatch $(1998: 162,213)$ also points out that his writing about the matter contains about 619 entries dealing with attempts to formulate a theory on humour.

Thus, in spite of diverse attempts to define the concept (cf. Sherrin 2001:154-157), one needs to note Addison's warning in 1711 (Sherrin 2001):

Among all kinds of writing, there is none in which authors are more apt to miscarry than in works of humour, as there is none in which they are more ambitious to excel. (p. 154)

Authors find a workable definition for the subject elusive and unattainable. Synonyms of the concept highlight the problem (cf. Sinclair 1995). Cresswell (2009:189) points out that a sense of humour may refer to things being funny in different ways. She notes Hay's (Sherrin 2001:155, n. 20) classification of funny things as either 'funny ha-ha' or 'funny peculiar', encapsulating the distinctions in meaning between what is amusing and what is strange. Perhaps this view creates more space for the understanding of the subject.

Greenstein (1992:331) distinguishes a complex category, namely 'wit in word' from 'wit in thought', and 'harmless wit' from 'tendentious wit'. According to him, the latter one is encountered in the biblical prophets. On occasion witticism is extended to include 'wicked wit' (Enright 2001:7-160). Procter (1995:693) distinguishes two nuances of meaning: humour as 'amusement' (things) and humour as 'mood' (feelings). Others indicate that someone may be out of humour (sick or gallic), that is, that he or she appears to be logical and intellectual, presenting wit rather than humour (Pearsall \& Trumble 1996:690; Gulland \& Hinds-Howell 1994:120, 127, 189). The concept may produce good, ill, evil or bad humour (Kirkpatrick 1999:524).

Apart from, for example folk, ethnic or Jewish humour, ${ }^{2}$ Botha (2009) enumerates several types of the concept, namely small, low, high, true, ironical, satirical, objective and subjective humour. Fowler (1983:252-253) decided that a tabular arrangement of the nuances in the meaning 2.Spalding (1978), Ben Zeev (2001), Kellner (1998) and Roup (2005). of humour would be of more use to clear up the confusion. He ended up with 40 terms strung together in an attempt to grasp the meaning (cf. Radday 1990:23, 25[21-38]).

As mentioned above, others chose to explore a way whereby the concept can be described with the aid of, or in terms of, selected literary types.

\section{Humour and literary types}

As stated earlier, some take it for granted that humour is part and parcel of the Bible. This conviction is supported by the opinion that it is only fair to expect that the Bible, 'the Book of books', naturally presents literary types with a humorous tone. In some cases, whole biblical books have been classified as humorous literature. ${ }^{3}$

\section{Humour and puns (wordplay)}

According to some authors, puns are considered special vehicles for humorous ideas in literature, including the Bible. Some lexicons (e.g. Sinclair 1995) define puns as the instruments to exploit ambiguities and innuendoes for humorous effect.

Harrison (1978:224-225) classifies alleged cases of humour under the substantive of 'wit'. He judges that puns may be regarded as the most prominent conveyor of wit. However, he also argues that the pun was most forcefully developed by the prophets, who used it with deadly effect to proclaim the destiny of a disobedient Israel (e.g. Am 5:5; 8:2; cf. Hs 8:7; Is $5: 7 ; 34: 14 ; 54: 6 ;$ Jr 2:12; 3:22; Zch 9:5). Harrison also indicated that laughter is expressed in the Old Testament by, what he judges to be, satire (Job 12:2), sarcastic and satirical ridicule by Elijah of the Baal prophets (1 Ki 18:26-29), irony of Haman being unwittingly the cause of his enemy's promotion (Es 6:1-11), and Haman's retribution in being hanged on his own gallows (Es 5:14-7:10; cf. Mi 2:6-7, 11; Nah 3:1-19). However, sometimes the prophets were mocked by the people as well (cf. Jr 20:7).

\section{Humour, tragedy and comedy}

According to the lexicons (Sinclair 1995), in present day terms tragedy is a play in which the protagonist falls to disaster through the combination of a personal failing and circumstances with which he or she cannot cope. It also represents any dramatic or literary composition dealing with sombre themes and ending with disaster. Comedy on the other hand is a dramatic work with a light and amusing character - a play in which the main characters triumph over adversity.

Thus, as can be expected, articles dealing with the Bible in terms of tragedy and comedy are rife (Exum 1984:5-96). Some have found that the latter twosome dominates the narratives dealing with Isaac, Samson, Saul and Esther - also Hosea and Daniel (cf. Pierson 1994:331-336).

3.Cf. for example Radday and Brenner (1990), Corrigan (1981), Cox (1970) and Exum (1985). 
However, arguments dealing with tragedy and comedy in this context have been met with approval as well as disapproval (Exum 1984:99-148; Robertson 1984). Comedy is a case in point (Gladson 1993:231). Most books dealing with literary types in the Old Testament do not mention literary types related to comedy. ${ }^{4}$ Coats (1985:7-132), in his work on saga, legend, tale, novella and fable, finds no humourrelated literature in the Bible. Foreign key words (in Hebrew and Greek) are sometimes listed in these works, but terms for laughter are excluded (Rendtorff 1986:303; La Sor et al. 1982:695-696; cf. Wielenga 1960:60-70).

Alter (1981:49-50) discusses literary types without reference to humorous indicators, including the passages where Sarah's predicament is mentioned. Writing in unison, Alter and Kermode $(1989: 31,125,239,437,574)$ claim to have found cases where comedy appears in biblical passages. They consider the narrative dealing with the preparation of girls with different ointments to bring out their beauty when appearing before the Persian king in the imperial court in Susa as comedy (Es 2:3,9,12). If the latter was true, how should one understand the case of Ruth who washed herself to meet Boaz (Rt 3:3)? And the woman who did not anoint herself when appearing before king David in order to mislead him in connection with the return of his son, Absalom (2 Sm 14:2; cf. Dn 10:3)? These authors also purport that the episode dealing with the captivity of the Ark of the Covenant (1 Sm 4-6; 2 Sm 6) has comic touches. The Ark, which was usually considered an object of sacral awe in Israel, now causes terror amongst their enemies. The same applies to the story of Jonah, where humans (and animals) covered in sackcloth cry unto God (Jnh 3:5-10).

Greenstein (1992:331-332), discussing comedy and the comical, refers to the undoing of the Egyptian Pharaoh and the impalement of Haman. Greenstein (1992:330-332) also highlights the farce and irony, and enumerate some victimdirected types that represent an ongoing subdivision:

- Sarcasm: Joseph's brothers calling him 'master of dreams' (Gn 37:19).

- Ridicule: The woman crushing Abimelech's head (Jdg 9:53-54).

- Satire: Attacks on foreign gods (Is 44:9-20).

- Parody: Jonah's values being the inverse of those of other prophets (Jnh 1-4).

- Trickery: Laban's deceit of Jacob and Jacob's breeding trick (Gn 29; 30:29-43).

- Verbal wit: Jeremiah's addressing the heavens (Jr 2:12).

- Proverbial humour: Like a gold ring in a swine's snout equals a beautiful woman without discretion (Pr 11:22).

Metcalf (2002:149) adds 'riddles' to this list (e.g. Jude 14: 12-20). However, Greenstein (1992) also avers that the judge Ehud's killing of Eglon, the enemy of Israel, may serve as an example of humour. Ehud is left-handed and slices Eglon's stomach with his sword, allowing his intestines to be spilled on the flour. Obviously this is brutal murder, not humour.

4.Lack of space prevents listing titles without reference to humour or comedy.
Murphy (1981:18) refers to Whedbee (1977:1-39), who views Job as comedy. This author defines comedy in terms of two central ingredients: a vision of incongruity that involves the ironic, the ludicrous and the ridiculous, and a basic storyline in which the hero ultimately arrives at happiness and is restored to a harmonious society. However, biblical commentaries on Job do not seem to find any indication that Job represents an example of comedy (Reichert 1958:xiii-xx). The book of Job actually deals with the question of why the righteous suffer.

Again, utilising literary notions to indicate what humour is, seems questionable too. Apparently no evidence exists that proves beyond doubt that the present classification of written material into different literary types represents humorous characterisation, as has been practised at the time of the writing of the Bible.

Perhaps one should start with religion itself and try to find a way to deal with the problem of a definition applicable to the subject.

\section{Is humour an integral part of religion?}

Does religion itself give rise to humour? Donnely (1992) promotes an appreciation for the phenomenon of humour and is adamant:

... that divorcing humour from religion is potentially destructive of true religion even when the separation is done with the best of motives, or in ignorance, the results are disastrous because we rob ourselves of the lightness and freedom necessary to notice and then to adore God. (p. 385)

Others identified 'religious' or 'Christian jokes' as a subgenre in its own right (Hempelmann 2003). However, many of these jokes are characterised by crudeness or even blasphemy.

This tendency claims that blasphemy is actually comical: 'Blasphemy is merely the comic verse of belief' (Behan quoted in Rees 2001:417, n. 8). This statement borders on gross blasphemy, not the comical.

Looking at certain texts, the reader will realise that laughter, generally speaking, refers to unwanted attitudes of humans.

\section{Laughter and human attitude}

Laughter, unfortunately, does not always serve or express cordiality. Beuken (1961:127-132) compared the laughter of Greek deities with that of the God of Israel. The gods of the Greeks were presented as ever-laughing, whatever the circumstances of those who worship them.

In contrast with these deities, the God of Israel is depicted as the One who laughs only on occasion. In fact, the Old Testament recorded only four instances of Yahweh laughing (Ps 2:4; 37:13; 59:9 [Eng v. 8]; Pr 1:20-26). Laughter is further restricted by the reality that Yahweh's laughter is not an 
expression of cordiality. In all these texts, God's laughter is qualified by superiority, or more specifically, as laughter associated with his judgement.

Beuken (1961:127-132) also pointed out that, in contradistinction to the Greeks whose culture speaks mainly of seeing their gods and enjoying the latter's laughter, the God of Israel is presented as the One who speaks and expects Israel to listen to his Word and obey it. Against this background, it seems clear that the Old Testament does not rank laughter throughout as an ever-positive expression of human attitude. In Ecclesiastes 7:6, for example, laughter is associated with foolishness, whilst committing a detestable deed is an occasion for fools to laugh (Pr 10:23, cf. Mt 9:24; [Lk 6:21]; Ja 4:9). However, God's people did find reason to rejoice, for example to laugh when God allowed his people to return from exile. In Psalms 126:1-2, the LXX uses the Greek word chara, a standard form expressing true joy. In another way, laughter may express the attitude of Israel's enemies towards God's people when they suffered (Lm 1:7). However, Wisdom will laugh at those who disregard this and consequently suffer themselves (Pr 1:20-26). Over against this reality, the reader will find that the righteous will laugh when their enemies are destroyed (Ps 52:8).

\section{The origin of the humour concept: A historical perspective}

It is important to determine the time when the phenomenon originated, that is, before, during or after the compilation of the Old Testament. Can it be taken for granted that humour was present in speech and literature from time immemorial, thus representing a very ancient ever-present phenomenon? Or did the idea of humour originate more recently? Were the authors at the time of the writing of the Bible acquainted with the phenomenon of humour as understood in the Western world today? Apparently, Jewish and Christian lore and legend did not make provision for humour (Unterman 1997; Metford 1983).

Determining the time when humour originated is crucial. Harrison (1978:224) opts for the 16th century. According to Critchley (2002:71-72, 82-84), humour is a distinctively modern notion and is linked to the rise of the democratic public sphere in countries like Britain in the 18th century. Critchley also pointed out that 'court jesters' did not survive the 17th century in Britain - the last recorded 'fool' being Henry Killigrew, appointed to William III in 1694.

Discussing the term fun, Cresswell (2009:189) notes that its current sense probably only dates from the 18th century. Cresswell (2009:15) also indicates that the term amuse originally had more to do with deception than entertainment or humour - dating from the late 15th century, it meant to delude or deceive. In the 17th and 18th centuries, to 'amuse' someone usually meant to divert his or her attention in order to mislead them. In addition, Cresswell (2009:216) points out that the association of humour with amusement arose in the late 17th century (Perlmutter 2000). Operating in the sense of caprice or whim, Harrison (1978:224) indicates that the term humour was commonly found in 16th century writings and later.

The latter is decisive for this article since it will indicate whether the meaning of humour as understood in the Western world today is the same as that which operated around the time of the writing of the Bible. The origin of the Bible, and particularly the Old Testament, dates back to a time before the onset of the phenomenon of humour as harmless amusement. Even if it were possible to ascertain that the writing down of the Old Testament took place around the time of the Babylonian Exile ( $\pm 586-539 \mathrm{BC})$, it is still far removed from the time when the development of the idea of humour, as understood in the Western world today, took place.

If these statements were taken into consideration, it would seem that an exercise regarding the usage of humour in the Bible is excluded from the outset.

\section{Distinguishing between 'Oriental' and 'Western' humour}

Again, part of the problem regarding the concept of humour relates to the way it is understood in Western culture versus non-Western culture. In non-Western culture it would appear that humour consisted mainly of crude language. As set out above, some of the most important aspects regarding the definition of humour relates to its historical, cultural and religious background and context. Ignoring this reality would show why several authors rake together the maximum number of examples to prove that the Bible deals with humour on a broad basis. ${ }^{5}$

However, others are more cautious in their classification of passages, texts or words. Harrison (1978:224) indicates that Oriental humour differs markedly from that of modern Western countries and cultures. Literature originating in the former sphere reflects a depressingly insecure way of life. The life situation in the ancient world did not provide many opportunities for laughter. When people did laugh, it often happened whilst they were drinking alcoholic beverages. If this presentation of the phenomenon were feasible, one can accept that the literature from that time would bear witness to the characterisation as indicated. This includes, amongst others, that the said literature was dominated to a certain extent by concepts or expressions with a negative, humiliating dimension - and not innocent amusement. Thus, as part of ancient Near Eastern literature, biblical texts need to be read with this in view.

\section{Humour in the ancient Near East and Israel}

Examples of humour identified by Foster (1992:330) are not only scarce in Sumerian and Akkadian texts, but speak more of insult and injury, bad language, ribald jokes and 5.See, for example, Stinespring (1980), Foster (1992), Greenstein (1992) and Culpepper (1992:333). 
improper, ill-mannered and rude behaviour. Allegedly, cases of humorous expressions have been traced in Mesopotamia (before 2150-2050 BC). However, the latter, as with other ancient nations including Israel, apparently did not consider an association between humour or its substitute and religion. This appears in stark contrast with the modern attitude, where religion and humour often appear intertwined in conversations and literature (allegedly also in the Old Testament). In the minds of oriental people, including Israel, religious beliefs, customs, duties and the like simply did not admit of anything but the most sober of interpretation or expression (Harrison 1978:224). Bienkowski and Millard (2000:148-149), in their discussion of humour amongst ancient oriental nations only, cite cases of crude language in general and present this as humour.

Greenstein (1992:330-331) argues that, since humour appears to be a universal phenomenon and has been recognised in other ancient Near Eastern literature, one may expect to find it in ancient Israelite literature too - even in texts as serious in purpose as the Hebrew Scriptures. He acknowledges that the Bible has no term for humour as such, but avers that it has an etymologically related set of verbs for 'to laugh'.

The presence of humour in texts is evasive and the meaning of the word rather illusive. This can also be seen in the uncertainty of the identification and interpretation of the concept in ancient Eastern texts like the Egyptian story of Sinuhe. Meltzer (1992:327) interprets this text as humorous. However, the corresponding story in a Hebrew narrative (Gn 37-50), namely the rejection of Joseph and his gaining royal power in Egypt, does not seem to reveal a hint of humour.

According to Herion (1992), the theological assumption in the previous century that religion is serious, has been abandoned by many - some of whom have pointed out that humour can be a powerful vehicle for making important points, whilst others go further and insist that biblical writings may have been intended primarily to entertain the reader. Nevertheless, he reminds the reader that, since humour is greatly dependent upon the cultural conventions of the moment, it is difficult for the modern Western mindset to appreciate what was humorous in ancient Israel or in the early Christian Church.

Meltzer (1992:326) argues that anyone attempting to discuss the humour of a radically different and distant culture will indubitably reveal much more about his or her own sense of humour than about that of the people under study. Cultural differences make it doubtful whether we can correctly identify all the references that the ancient nations intended as humorous, without errors of both commission and omission. It is even more doubtful whether one can grasp the impact of their humour on its intended audience. Thus, apparently humour did not function prominently amongst the peoples of the ancient Near East - at least not in the sense that the phenomenon is understood in the Western world today. On the contrary, laughter amongst the ancients seems to have been primarily aimed at ridiculing, belittling or despising fellow humans. This is known as the 'laughter of superiority' and is related to violent humour - a tendency that existed under totalitarian regimes (Critchley 2002:3, 12, 65-76, 82, 94).

\section{Conclusion with a note on hermeneutics Laughter and mockery}

On the one hand, the Old Testament mentions 'joyful laughter' that, for example accompanied the birth of a child (e.g. Gn 21:6; cf. Lk 1:14, 19b, 58). On the other, the ideas of scorn and derision actually seem to have been widely conveyed in laughter (Job 22:19; Ps 22:7; 52:6). Laughter in the Bible is not associated with pleasure or cordiality.

\section{Read text objectively}

Most of those who occupy themselves with biblical exegesis and exposition are aware of the challenges of reading a text objectively. In contradistinction to this ideal, interpreters seem to have reached the stage where they feel free to ignore all historical, grammatical, archaeological, philological, theological and hermeneutical tools in order to understand texts. Therefore, authors are guided by their personal views or paradigm when interpreting words, texts or passages. This is the so-called 'reader's response' approach in contrast to the 'author's intentionality' (Landy 1990; Donnely 1992). No hermeneutical parameters are provided to guide the researcher - only the idea of a post- 18 th century WestEuropean understanding, when laughter took on an association of amusement. Perhaps one may say that authors seem to apply a hermeneutic of humour to selected biblical texts, or practise 'projection hermeneutics' - in this case superimposing the idea of humour onto texts. Actually, it would seem that conclusions reached, ignore the reality expressed in the Old Testament, namely that a myriad of texts address or display jest or mockery - but not amusement.

\section{No Hebrew term for humour}

However, whatever arguments may be brought forward to prove that humour does operate in the Bible, one author's remark hovers over the issue. Greenstein (1992:330-331) acknowledges that the Bible has no Hebrew term for humour as such, and yet, he defends the idea that humour is part of the biblical setup. Authors simply accept, without question, that the Bible deals with humour, but virtually none of these authors are able to produce a single argument of proof, based on sound explicatory guidelines, for their findings. From the contexts it is clear that the thrust of texts cited does not leave room for humour. In some cases the explanations of examples viewed as bearing a humorous character appear ridiculous in themselves.

\section{Acknowledgements Competing interests}

The author declares that he has no financial or personal relationship(s) that may have inappropriately influenced him in writing this article. 


\section{References}

Alter, R., 1981, The art of biblical narrative, Basic Books, New York.

Alter, R. \& Kermode, F., 1989, The literary guide to the Bible, Fontana Press, London.

Ben Zeev, A., 2001, The Xenophobe's guide to the Israelis, Oval Books, London.

Beuken, W.A.M., 1961, 'Goddelijke lach: Een vergelijkend onderzoek van de antieke literatuur en de Bijbel', Bijdragen 22, 117-132.

Bienkowski, P. \& Millard, A. (eds.), 2000, Dictionary of the ancient Near East, British Museum Press, London.

Boekkooi, P., 2010, 'Terrorisme kry hier komiese inslag: Filmresensies', Die Burger, 29 October, bl. 20

Botha, W. (red.), 2009, Elektroniese WAT: Woordeboek van die Afrikaanse Taal (A-R), computer software, Fast Folio, Nasou Via Afrika, Stellenbosch.

Coats, G.W., 1985, Saga, legend, tale, novella, fable: Narrative forms in Old Testamen Literature, JSOT Press, Sheffield. (JSOT Supplement Series, Book 35).

Corrigan, R.W., 1981, Comedy: Meaning and form, 2nd edn., Harper \& Row, New York. Cox, H., 1970, The feast of fools: A theological essay on festivity and fantasy, 2nd edn., Harvard University Press, Cambridge.

Cresswell, J. (ed.), 2009, The insect that stole butter?, University Press, Oxford.

Critchley, S., 2002, On humour, Routledge, London.

Culpepper, R.A., 1992. 'Humour and wit in the New Testament', in D.N. Freedman (ed.), The Anchor Bible Dictionary, vol. $3(\mathrm{H}-\mathrm{J})$, pp. 333, Doubleday, New York.

Daintith, J. \& Stibbs, A. (eds.), 1994, Bloomsbury treasury of quotations, Bloomsbury Publishing, London.

De Villiers, J.L., 2002, Tot lof van dwaasheid (Encomium Moriae deur Desiderius Erasmus), transl. J.L. de Villiers, Protea Boekhuis, Pretoria.

Donnely, D., 1992, 'Divine folly: Being religious and the exercise of humor', Theology Today 48(4), 385-398. http://dx.doi.org/10.1177/004057369204800402

Enright, D. (ed.), 2001, The wicked wit of Winston Churchill, Michael O'Mara Books Limited, London.

Exum, J.C. (ed.), 1984, Tragedy and comedy in the Bible, Scholars Press, Baltimore. (SBL Semeia 32)

Foster, B.R., 1992, 'Humour and wit in Mesopotamia', in D.N. Freedman (ed.), The Anchor Bible Dictionary, vol. 3 (H-J), pp. 328-330, Doubleday, New York.

Fowler, H.W., 1983, A dictionary of modern English usage, 2nd edn., University Press, Oxford.

Friedman, H.H., 2000, 'Humor in the Hebrew Bible', Humor: International Journal of Humor Research 13(3), 257-85. http://dx.doi.org/10.1515/humr.2000.13.3.257

Friedman, H.H., 2002, 'Is there humor in the Hebrew Bible? A Rejoinder', Humor: International Journal of Humor Research 15(2), 215-222. http://dx.doi. org/10.1515/humr.2002.012

Gladson, J.A., 1993, 'Job', in L. Ryken \& T. Longman III (eds.), A complete literary guide to the Bible, pp. 230-244, Zondervan Publishing House, Grand Rapids.

Greenspoon, L., 2013, Humor in the Old Testament, University Press, Oxford.

Greenstein, E.L., 1992, 'Humour and wit in the Old Testament', in D.N. Freedman (ed.), The Anchor Bible Dictionary, vol. $3(\mathrm{H}-\mathrm{J})$, pp. 330-333, Doubleday, New York.

Gulland, D.M. \& Hinds-Howell, D., 1994, The Penguin dictionary of English idioms, Penguin Books, London.

Harrison, R.K., 1978, 'Humour', in M.C. Tenney (ed.), The Zondervan pictoria encyclopedia of the Bible, vol. 3 (H-L), pp. 224-226, Zondervan Publishing House, Grand Rapids.

Hempelmann, C.F., 2003, “"99 Nuns Giggle, 1 Nun Gasps": The not-all-that Christian natural class of Christian jokes', Humor: International Journal of Humor Research 16(1), 1-31. http://dx.doi.org/10.1515/humr.2003.003

Herion, G.A., 1992, 'Humour and wit', in D.N. Freedman (ed.), The Anchor Bible Dictionary, vol. $3(\mathrm{H}-\mathrm{J})$, pp. 325-326, Doubleday, New York.

Jordaan, W., 2007, 'Lag kan maak of breek', Rapport, 21 Januarie, bl. 7.

Kellner, E., 1998, Yiddish with a smile: A collection of words, phrases \& witticisms, CTP Book Printers, Cape Town.

Kirkpatrick, B. (ed.), 1999, Brewer's concise dictionary of phrase and fable, Helicon, Oxford.

Landy, F., 1990, 'Humour as a tool for biblical exegesis', JSOT Bible and literature series 23, 99-115.
La Sor, W.S. et al.(eds.), 1982, Old Testament survey, Eerdmans, Grand Rapids.

Malherbe, F., 2007, Spreekkamerstories met' $n$ lepel vol lag, Human \& Rousseau, Cape Town.

McKenzie, E.C., 1980, 14,000 Quips and quotes for writers and speakers: Words of wisdom, wry witticisms and quick comebacks, Wings Books, New York.

Meltzer, E.S., 1992, 'Humour and wit in Ancient Egypt', in D.N. Freedman (ed.), The Anchor Bible Dictionary, vol. 3 (H-J), pp. 326-328, Doubleday, New York.

Metcalf, F. (ed.), 2002, The Penguin dictionary of modern humorous quotations, 2nd edn., Penguin Books, London.

Metford, J.C.J., 1983, Dictionary of Christian lore and legend, Thames \& Hudson, London.

Murphy, R.E., 1981, Wisdom literature: Forms of Old Testament Literature, vol. 13, Eerdmans, Grand Rapids.

Overduin, J., 1978, Faith and victory in Dachau, Paideia Press, St Catherines, Ontario.

Parker, A., 2010, 50 People who stuffed up South Africa, Burnet Media, Kenilworth.

Pearsall, J. \& Trumble, B., 1996, Oxford English Reference Dictionary, 2nd edn., University Press, Oxford.

Perlmutter, D.D., 2000, 'Tracing the origin of humor', Humor: International Journal of Humor Research 13(4), 457-468. http://dx.doi.org/10.1515/humr.2000.13.4.457

Pierson, A.T., 1994, World's guide to understanding the Bible, AMG Publishers, USA

Preuss, H.D., 1971, 'Verspottung fremder Religionen im Alten Testament', Beiträge zur Wissenschaft vom Alten (und Neuen) Testament, Leipzig, Stuttgart. (BWANT 92).

Procter, P. (ed.), 1995, Cambridge International Dictionary of English, University Press, Cambridge.

Rabe, L., 2011, 'Woorde wat verwond: Brandpunt', By, Die Burger, 22 Oktober, bl. 6.

Radday, Y.T., 1990, 'On missing the humour in the Bible', in Y.T. Radday \& A. Brenner (eds.), On humour and the comic in the Hebrew Bible, pp. 12-38, Almond Press, (eds.), On hu
Sheffield.

Radday, Y.T. \& Brenner, A. (eds.), 1990, On humour and the comic in the Hebrew Bible, Almond Press, Sheffield.

Rees, N., 2001, Cassell's humorous quotations, Cassell \& Co, London.

Reichert, V.E., 1958, Job, Soncino Press, London.

Rendtorff, R., 1986, The Old Testament: An Introduction, Fortress Press, Philadelphia.

Robertson, D., 1984, 'Tragedy, comedy, and the Bible - A response', in J.C. Exum (ed.), Tragedy and comedy in the Bible, pp. 99-105, Scholars Press, Baltimore. (SBL Semeia 32).

Roup, J., 2005, Boerejood, Jancana Media, Johannesburg.

Sherrin, N. (ed.), 2001, The Oxford dictionary of humorous quotations, 2nd edn., University Press, Oxford.

Simpson, D.P., 1979, Cassell's Latin English Dictionary, Cassell, London.

Sinclair, J.M., 1995, Collins English Dictionary, Harper Collins, Glasgow.

Spalding, H.D. (ed.), 1978, A treasure-trove of American Jewish humour, Jonathan David Publishers, New York.

Stinespring, W.F., 1980, 'Humour', in G.A. Buttrick (ed.), The Interpreter's Dictionary of the Bible: An illustrated Encyclopedia, vol. 2 (E-J), pp. 660-662, Abingdon Press, Nashville.

Svebak, S., 1996, 'The development of the sense of humor questionnaire: From SHQ to SHQ-6', Humor: International Journal of Humor Research 9(3 \& 4), 341-361.

Swanepoel, M., 2003, 'Lagmedisyne van die Kanniedoods', Beeld Plus, 2 Augustus, bl. 3.

Theron, P.F., 1995, 'Liberating humour - Calvinism and the comic vision', NGTT (Dutch Reformed Theological Journal) 36(4), 593-603.

Theron, P.F., 1996, 'Liberating humour - Calvinism and the comic vision', in A. van Egmond \& D. van Keulen (eds.), Freedom, pp. 208-224, Callenbach, Baarn.

Theron, P.F., 2004, 'The "God of war" and his "Prince of peace", NGTT (Dutch Reformed Theological Journal) 45(1 \& 2), 118-126.

Unterman, A., 1997, Dictionary of Jewish lore and legend, Thames \& Hudson, London.

Veatch, T.C., 1998, 'A theory of humor', Humor: International Journal of Humor Research 11(2), 161-215. http://dx.doi.org/10.1515/humr.1998.11.2.161

Whedbee, W., 1977, 'The comedy of Job', Semeia 7, 1-39.

Wielenga, B., 1960, De Bijbel als boek van schoonheid, J.H. Kok, Kampen. 